\title{
Komplikasi Tiroidektomi Endoskopik pada Nodul Tiroid Ganas Sebuah Tinjauan Pustaka
}

\author{
IGN Gunawan ${ }^{1}$, Annisa Syafitri ${ }^{1}$ \\ ${ }^{1}$ Divisi Bedah Onkologi, Departemen Ilmu Bedah, \\ Fakultas Kedokteran Universitas Indonesia, Rumah Sakit Cipto Mangunkusumo \\ ${ }^{2}$ Departemen Ilmu Bedah, \\ Fakultas Kedokteran Universitas Indonesia, Rumah Sakit Cipto Mangunkusumo
}

\begin{abstract}
Abstrak
Latar Belakang. Tiroidektomi endoskopik merupakan teknik bedah tumor yang populer saat ini. Teknik ini dapat mengatasi salah satu kekurangan tiroidektomi terbuka konvensional yaitu parut operasi. Tiroidektomi endoskopik dikerjakan pada nodul tiroid jinak berukuran kurang dari 5-6 cm. Saat ini tiroidektomi endoskopik sudah mulai dilakukan pada nodul tiroid ganas. Hal ini menjadi landasan berpikir bagi peneliti untuk menulis sebuah tinjauan literatur komplikasi tiroidektomi endoskopik pada nodul tiroid ganas ditinjau dari cedera nervus laringeus, hipoparatiroid, dan nyeri pascabedah berdasarkan bukti ilmiah tertinggi.

Metode. Suatu tinjauan literatur yang dilaksanakan di Departemen Ilmu Bedah FKUI-RSCM Divisi Bedah Onkologi pada November - Desember 2020. Metode penelitian dibuat dengan cara pencarian dan seleksi literatur pada situs-situs database Cochrane, PubMed, ScienceDirect, dan EbscoHost yang sesuai dengan ilustrasi kasus menggunakan kata kunci "endoscopic thyroidectomy", AND "thyroid tumor" OR "thyroid cancer” OR "thyroid carcinoma” AND “laryngeal nerve injury” OR "hypoparathyroid” OR "postoperative pain” Kemudian dilakukan pemilihan studi berdasarkan kriteria inklusi dan eksklusi literatur. Studi yang terpilih dilakukan penilaian terhadap studi, karakteristik subjek, tahun studi, dan outcome dari masing-masing studi.

Hasil. Didapatkan 160 artikel yang kemudian dilanjutkan dengan telaan kritis sehingga didapatkan 10 studi dalam penelitian. Dari 10 studi, 8 studi menilai mengenai komplikasi cedera nervus laringeus dan didapatkan 1 studi yang memiliki perbedaan bermakna terkait komplikasi cedera nervus laringeus. Terdapat 4 studi yang menunjukkan angka hipoparatiroid tiroidektomi endoskopik lebih tinggi namun hanya 1 yang memiliki perbedaan bermakna. Nyeri pasca bedah diteliti pada 2 studi yang menunjukan VAS nyeri pascabedah di kedua kelompok tidak ada perbedaan.
\end{abstract}




\section{Tinjauan Pustaka}

Kesimpulan. Pada nodul tiroid ganas, teknik ini memiliki durasi pembedahan yang lebih lama serta tidak memiliki perbedaan dari segi komplikasi baik berupa cedera nervus laringeus, hipoparatiroidisme dengan tiroidektomi terbuka. Tiroidektomi endoskopik dapat menjadi pilihan dalam menatalaksana pasien karsinoma tiroid dengan risiko rendah.

Kata kunci: tiroidektomi endoskopik, nodul tiroid ganas, cedera nervus laringeus, hipoparatiroid, nyeri pascabedah

(ISSN 2723-7494 J Bedah Indonesia. 2021;49:50-66)

\section{Korespondensi Penulis:}

dr. Annisya Syafitri

Departemen Ilmu Bedah

Fakultas Kedokteran Universitas Indonesia, Rumah Sakit Cipto Mangunkusumo

Email : syafitriannisa@gmail.com 


\section{Tinjauan Pustaka}

\section{Pendahuluan}

Tiroidektomi endoskopik merupakan teknik bedah tumor tiroid yang sedang populer saat ini. Teknik ini dapat mengatasi salah satu kekurangan tiroidektomi terbuka yang konvensional, yaitu timbulnya parut operasi. Tiroidektomi endoskopik dikerjakan pada nodul tiroid jinak berdiameter kurang dari 5-6 cm. Bekas luka operasi menjadi perhatian terutama pada populasi Asia yang sering mengalami parut hipertrofi setelah tiroidektomi. Pada teknik tiroidektomi endoskopik, parut operasi tersebut dapat disembunyikan sehingga secara estetik lebih baik.

Sejak tiroidektomi endoskopi diperkenalkan pertama kali, kini telah dikembangkan beragam akses, seperti melalui aksila, dinding anterior dada, payudara, retroaurikula, atau transoral. ${ }^{1}$ Secara teknis tiroidektomi endoskopik merupakan prosedur yang sulit dan membutuhkan waktu pembelajaran yang panjang. ${ }^{1,2}$

Saat ini teknik tiroidektomi endoskopik sudah mulai dilakukan pada nodul tiroid ganas. Walaupun demikian, belum ada konsensus mengenai indikasi tiroidektomi endoskopik di nodul tiroid ganas.. Hal ini menjadi landasan berpikir bagi peneliti untuk menulis sebuah tinjauan literatur komplikasi tiroidektomi endoskopik pada nodul tiroid ganas ditinjau dari cedera nervus laringeus, hipoparatiroid, dan nyeri pascabedah berdasarkan bukti ilmiah tertinggi.

\section{Metode}

Penelitian ini merupakan suatu tinjauan literatur. Penelitian dilakukan di Departemen Ilmu Bedah FKUI-RSCM, divisi bedah onkologi pada NovemberDesember 2020. Metode penelitian dibuat dengan cara pencarian dan seleksi literatur pada situs-situs database Cochrane, PubMed, ScienceDirect, dan EbscoHost yang sesuai dengan ilustrasi kasus menggunakan kata kunci "endoscopic thyroidectomy", AND "thyroid tumor" OR "thyroid cancer" OR "thyroid carcinoma" AND "laryngeal nerve injury” OR "hypoparathyroid" OR "postoperative pain”. Dilakukan pemilihan studi berdasarkan kriteria inklusi dan eksklusi. Studi yang terpilih dilakukan penilaian terhadap studi, karakteristik subjek, tahun studi, tempat studi, dan outcome dari masing- masing studi.

Kriteria inklusi:

1. Studi pada pasien dengan nodul tiroid ganas

2. Desain studi berupa cohort, cross sectional, case series, dan case control 


\section{Tinjauan Pustaka}

3. Berbahasa Inggris

4. Tersedia dalam bentuk full-text

Kriteria eksklusi:

1. Studi pada hewan coba

2. Publikasi dalam bentuk korespondensi, editorial, maupun commentary

Hasil

Didapatkan 160 artikel dengan rincian berikut: sejumlah 82 artikel dari PubMed, 26 artikel dari Science Direct, 10 artikel dari Cochrane, dan 42 artikel dari EBSCOHost. Sejumlah 86 artikel dieksklusi karena tidak memuat kriteria yang diperlukan. Setelah itu dilanjutkan dengan telaah kritis sehingga didapatkan 10 studi dalam penelitian ini. Hasil pengkajian di atas menunjukkan bahwa 10 studi tersebut sesuai dan memenuhi kaidah pengkajian kesahihan, kepentingan, dan kemampuan dalam penerapannya. Maka dari itu, kesepuluh literatur tersebut akan ditinjau lebih lanjut dalam bagian selanjutnya.

\section{Studi "Single-Incision, Gasless,} Endoscopic Trans-Axillary Total Thyroidectomy: A Feasible and Oncologic Safe Surgery in Patients with Papillary Thyroid Carcinoma" oleh Kim dkk
Berdasarkan studi yang dilakukan oleh Kim dkk (2017), antara bulan Maret 2008 hingga Desember 2012, terdapat 1614 pasien yang menjalani pembedahan tiroidektomi bilateral total dengan diagnosis karsinoma tiroid papiler di departemen bedah RS Kangbuk Samsung. Setelah dilalukan proses eksklusi, terdapat 738 pasien yang dianalisis dalam studi ini, termasuk 200 pasien yang menjalani tiroidektomi endoskopik dan 538 pasien yang menjalani tiroidektomi terbuka.

\section{Studi "Comparison of long-term} surgical outcome between transaxillary endoscopic and conventional open thyroidectomy in patients with diferentiated thyroid carcinoma: a propensity score matching study" oleh Kim dkk

Kim dkk (2020) melakukan studi retrospektif terhadap 4299 pasien dengan karsinoma tiroid berdiferensiasi baik yang menjalani tiroidektomi endoskopik dan terbuka dari bulan Januari 2009 hingga Juni 2014 di RS Seoul St.Mary. Tabel 4.3.2 menjelaskan tidak terdapat perbedaan bermakna antara kedua grup dalam hal cedera nervus laringeus $(8,4 \%$ vs. $7,5 \% ; p=$ 0,576) dan kejadian hipokalsemia yakni sebanyak $1 \%$ dengan nilai $\mathrm{p}=0,2 .{ }^{17}$ 


\section{Tinjauan Pustaka}

3. Studi "Prospective comparative study of endoscopic via unilateral axillobreast approach versus open conventional total thyroidectomy in patients with papillary thyroid carcinoma" oleh Park dkk

Park dkk (2015) melakukan studi prospektif di korea dari bulan Januari hingga Desember 2011 di Universitas Soonchunhyang dengan melibatkan 152 pasien dengan 102 diantaranya menjalani tiroidektomi terbuka dan 50 pasien menjalani tiroidektomi endoskopik melalui unilateral axillobreast approach.

4. Studi "A comparative analysis of endoscopic thyroidectomy versus conventional thyroidectomy in clinically lymph node negative thyroid cancer" oleh Cho dkk

Selanjutnya, Cho dkk (2015) melakukan studi pada 49 pasien yang menjalani tiroidektomi endoskopik dengan bilateral axillobreast approach (BABA) dan 45 pasien yang menjalani tiroidektomi terbuka dalam kurun waktu Juli 2009 hingga Juni 2011 di Departemen bedah Universitas Konkuk Seoul.

Tabel 4 menunjukkan dari 45 pasien yang menjalani tiroidektomi endoskopik didapatkan 23 pasien yang mengalami hipokalsemia sementara dan tidak didapatkan pasien dengan hipokalsemia permanen. ${ }^{19}$ Terdapat 1 pasien yang mengalami suara serak karena cedera nervus laringeus yang membaik dalam waktu kurang dari 6 bulan dan 1 pasien yang mengalami suara serak lebih dari 6 bulan pada tindakan tiroidektomi endoskopik. Dari kedua komplikasi tidak ditemukan perbedaan yang bermakna.

\section{Studi "Comparison of Conventional} Open Thyroidectomy and Endoscopic Thyroidectomy via Breast Approach for Papillary Thyroid Carcinoma" oleh Tan dkk

Tan dkk (2015) melakukan studi pada 64 pasien pada rentang bulan Maret 2008 sampai Maret 2013, diantaranya terdapat 34 pasien yang menjalani tiroidektomi endoskopik dan 30 pasien yang menjalani tiroidektomi terbuka konvensional.

Pada tabel 5 menunjukkan studi ini tidak didapatkan kejadian hipokalsemia yg sementara pada tindakan tiroidektomi endoskopik. Didapatkan kejadian cedera nervus laringeus sementara pada 1 pasien dengan tiroidektomi endoskopik.

\section{Studi "Transoral endoscopic thyroidectomy for thyroid carcinoma: outcomes and surgical completeness in 150 single-surgeon cases" oleh Ahn dkk}




\section{Tinjauan Pustaka}

Ahn dkk (2019) melakukan studi pada 150 dan 125 pasien kanker tiroid yang menjalani pembedahan endoskopik dengan metode transoral endoscopic thyroid surgery vestibular approach (TOETVA) dan teknik konvensional. Pada grup TOETVA, persentase pasien dengan jenis kelamin perempuan mendominasi dengan angka 96,7\%, sedangkan pada grup tiroidektomi terbuka persentase pasien perempuan mencapai $71,2 \%$.

\section{Studi "Comparative study of gasless} endoscopic selective lateral neck dissection via the anterior chest approach versus conventional open surgery for papillary thyroid carcinoma" oleh Lin dkk

Lin dkk (2020) meneliti 91 pasien dengan karsinoma tiroid papiler yang menjalani tiroidektomi endoskopik gasless atau tiroidektomi terbuka pada bulan November 2008 hingga desember 2018 di RS Sun Yat Sen Guangzhou.

Tabel 7 menunjukkan nyeri pascabedah pada kelompok tiroidektomi endoskopik didapatkan rerata VAS 3 dan tidak berbeda dengan kelompok tiroidektomi terbuka. Tidak terdapat kasus cedera nervus laringeus pada kedua grup baik yang sementara maupun permanen. Namun ditemukan kejadian hipokaslsemia sementara pada 1 pasien di masing- masing grup.

8. Studi "Endoscopic Thyroidectomy in Anterior Chest Approach Versus Open Thyroidectomy for Patients with Papillary Thyroid Carcinomas, a Retrospective Study" oleh Yang dkk

Literatur selanjutnya yang ditelaah dilakukan oleh Yang dkk (2020). Studi tersebut melibatkan 197 pasien di China dalam kurun waktu Januari 2015 hingga Juli 2017 di RS Soochow Guangzhou, diantaranya 85 pasien menjalani tiroidektomi endoskopik dan 112 pasien menjalani tiroidektomi terbuka Tabel 4.3.8 menunjukkan tidak ditemukan adanya kasus cedera nervus laringeus dan hipokalsemia permanen pada kedua grup. ${ }^{23}$

9. Studi "Treatment of differentiated thyroid cancer: can endoscopic thyroidectomy via a chest-breast approach achieve similar therapeutic effects as open surgery?" oleh Qu dkk

Qu dkk (2018) melakukan studi terhadap 76 pasien kanker tiroid terdiferensiasi dalam kurun waktu Januari 2013 hingga April 2017, 40 diantaranya menjalani tiroidektomi endoskopik dan 36 lainnya menjalani tiroidektomi terbuka. 


\section{Tinjauan Pustaka}

Tabel 9 menunjukkan tidak terdapat perbedaan yang signifikan terkait kasus cedera nervus laringeus sementara pada kedua grup ( 0 vs $2,8 \%, \mathrm{p}=0,474) .{ }^{24}$ Tidak terdapat perbedaan signifikan pula terkait hipokalsemia sementar pada kedua grup $(10 \%$ vs $5,6 \%, p=0,771)$. Kejadian cedera nervus laringeus rekuren dan hipokalsemia permanen tidak ditemukan pada studi ini.

10. Studi "Comparison of conventional thyroidectomy and endoscopic thyroidectomy via axillo-bilateral breast approach in papillary thyroid carcinoma patients" oleh Kim dkk

Kim dkk (2015) melakukan studi pada 830 pasien yang menjalani tiroidektomi terbuka dan 173 pasien yang menjalani tiroidektomi endoskopik pada waktu Mei 2007 hingga Februari 2011. Tabel menunjukkan angka cedera nervus laringeus sementara pada 33 pasien dalam grup tiroidektomi terbuka (4\%) dan 12 pasien dalam grup tiroidektomi endoskopik $(6,9 \%$, $\mathrm{p}=0,104)$. Kasus cedera nervus laringeus permanen ditemukan pada 3 pasien dalam grup tiroidektomi terbuka $(0.4 \%)$ dan 1 pasien dalam grup tiroidektomi endoskopik $(0,6 \%, \quad p=0,532) .{ }^{25}$ Kasus kejadian hipokalsemia sementara ditemukan cukup banyak pada studi ini dimana sebanyak 22 kasus untuk tiroidektomi endoskopik dan 246 kasus pada tiroidektomi terbuka ( $\mathrm{p}=$ $<0,0001)$. Untuk kasus hipokalsemia permanen didapatkan 3 pasien untuk tiroidektomi endoskopik dan 15 pasien pada tiroidektomi terbuka.

\section{Pembahasan}

Pembedahan tiroidektomi endoskopik dari 10 studi yang dilakukan telah memiliki karakteristik yang hampir mirip. Jenis kelamin terbanyak yang melakukan operasi tersebut adalah perempuan Asia, sehingga populasi sampel dari studi- studi ini cukup sesuai dengan perempuan Indonesia yang juga merupakan perempuan Asia.

Walaupun pembedahan pada tiroidektomi endoskopik lebih lama dibandingkan tiroidektomi terbuka, namun dalam komplikasi pascabedah yakni cedera nervus laringeus dan hipoparatiroidisme angka kejadian komplikasi tersebut minimal.

Terdapat sejumlah studi yang menilai cedera nervus laringeus sebagai keluaran klinis, termasuk Kim dkk (2020), Park dkk (2015), Cho dkk (2015), Tan dkk (2015), Ahn dkk (2019), Yang dkk (2020), Qu dkk (2018), dan Kim dkk (2015). ${ }^{17-21,23-}$ ${ }^{25}$ Walaupun demikian, tidak terdapat adanya perbedaan bermakna secara statistik terkait 


\section{Tinjauan Pustaka}

kejadian komplikasi pada kedua grup dalam studi-studi tersebut. Adapun Lin dkk (2020) tidak menemukan adanya kasus cedera nervus laringeus sama sekali pada kedua grup. ${ }^{22}$ Hanya satu studi yang menemukan perbedaan bermakna terkait komplikasi cedera nervus laringeus yakni studi oleh Kim dkk (2017) yang menemukan bahwa tiroidektomi endoskopik memiliki angka kejadian cedera nervus laringeus yang lebih tinggi dibandingkan teknik konvensional yakni sebanyak 17 pasien yang mengalami cedera nervus laringeus sementara (15\% vs. $4,6 \% ; \mathrm{p}<0,001$.

\section{Pada kejadian hipokalsemia} sementara terdapat 4 studi yang melaporkan kejadian hipokalsemia sementara dengan jumlah lebih dari 20 pasien atau lebih dari 20\% studi tersebut adalah Kim dkk (2017), Park dkk (2015), Cho dkk (2015), dan Kim dkk (2015). 16,18,19,25 Pada studi Kim dkk (2017) ditemukan perbedaan bermakna terkait hipokalsemia dengan nilai $p$ $<0,001 .^{16}$

Terdapat 5 studi yang menyebutkan bahwa pembedahan tiroidektomi endoskopik dilakukan oleh satu orang spesialis bedah yang memilki pengalaman lebih dari 5 tahun sehingga angka komplikasi hipokalsemia maupun cedera nervus laringeus minimal bahkan tidak ada. ${ }^{19,20,21,22,23}$ Tan dkk menyatakan bahwa walaupun visualisasi endoskopi tergolong baik dan nervus laringeus dapat terlihat jelas oleh spesialis bedah yang berpengalaman, komplikasi tersebut tetap dapat terjadi kemungkinan karena kerusakan termal oleh skalpel ultrasonik. ${ }^{20}$

Hasil VAS nyeri pascabedah juga berada dikisaran yang sama pada tiroidektomi terbuka. Walaupun insisi kulit pada tiroidektomi endoskopik lebih kecil ukurannya, namun karena sayatan dapat lebih dari satu dan dibutuhkan diseksi jaringan yang dalam pada pembedahan tiroidektomi endoskopik sehingga kualitas nyeri pascabedah serupa dengan tiroidektomi terbuka.

Keterbatasan yang didapat dalam penyusunan tinjauan literatur ini adalah dari pencarian jurnal-jurnal yang didapat sebagaian besar jurnal berasal dari dua negara saja yakni Cina dan Korea Selatan dengan spesialis bedah yang sudah berpengalaman dibidang endoskopik sehingga komplikasi yang timbul minimal atau tidak ada. Selain itu, pada komplikasi nyeri pascabedah tidak banyak jurnal yang melalukan penilaian terhadap komponen tersebut. Pada 10 jurnal, hanya ada 2 jurnal yang menilai nyeri pascabedah. 


\section{Tinjauan Pustaka}

\section{Kesimpulan}

Pada nodul tiroid ganas, teknik tiroidektomi endoskopik memiliki durasi pembedahan yang lebih lama, sehingga tidak ada perbedaan dari segi komplikasi, baik berupa cedera nervus laringeus dan hipoparatiroidisme, dengan tiroidektomi terbuka. Namun, tiroidektomi endoskopik tetap dapat menjadi pilihan dalam menatalaksana pasien dengan karsinoma tiroid dengan risiko rendah.

\section{Saran}

Diperlukan adanya penelitian lebih lanjut berupa studi prospektif, multisentris, dan bersifat terkontrol acak pada populasi masyarakat Asia, terlebih Indonesia, atau tinjauan sistematis dengan level of evidence yang lebih tinggi.

\section{Daftar Pustaka}

1. Sobri FB, Azhar Y, Wibisana IGN G, Susilo HD. Manajemen Terkini Kanker Tiroid, Oral, dan Kelenjar Saliva Edisi 1. Sagung Seto. 2019

2. Hong JH, Kim WS, Koh YW, Lee SY, Shin YS, Koo YC, et al. Endoscopic thyroidectomy via an axillo-breast approach without gas insufflation for benign thyroid nodules and micropapillary carcinomas: preliminary results. Yonsei Med J. 2011;52(4):64354

3. Dhingra JK, Raval T, Gosselin BJ, et al. Minimally Invasive Surgery of the Thyroid. New York: Medscape; 2011
[Updated 2011 March 16; cited 2020 Sept 24]. Available from: http://emedicine.medscape.com/article/ 1298816-overview\#a0199

4. McHenry CR, Phitayakorn R. Follicular adenoma and carcinoma of the thyroid gland. Oncologist. 2011;16(5):585-93.

5. Soerachmad S. Pengawasan lanjut pasca operasi tiroid. In: Naskah lengkap pelatihan penatalaksanaan penyakit tiroid bagi dokter umum. PERKENI Jaya. Jakarta: Pusat Penerbitan Departemen Ilmu Penyakit Dalam Fakultas Kedokteran Universitas Indonesia. 2008. p. 103 - 14

6. Bjorndal K, Krogdahl A, Therkildsen $\mathrm{MH}$, Overgaard J, Johansen J, Kristensen CA, et al. Salivary gland carcinoma in Denmark 1990-2005: a national study of incidence, site and histology. Results of the Danish Head and Neck Cancer Group (DAHANCA). Oral Oncol. 2011;47(7):677-82

7. National Comprehensive Cancer Network. Head and Neck Cancer. Guideline. 2016

8. El-Labban GM. Minimally invasive video-assisted thyroidectomy versus conventional thyroidectomy: A singleblinded, randomized controlled clinical trial. J Minim Access Surg. 2009;5(4):97-102.

9. Dobrinja C, Trevisan G, Makovac P, Liguori G. Minimally invasive videoassisted thyroidectomy compared with conventional thyroidectomy in a general surgery department. Surg Endosc. 2009;23(10):2263-7.

10. Chen C, Huang S, Huang A, Jia Y, Wang J, Mao M, et al. Total endoscopic thyroidectomy versus conventional open thyroidectomy in thyroid cancer: a systematic review and meta-analysis. Therapeutics and Clinical Risk Management. 2018;14:2349-61

11. Suyatno, Pasaribu ET. Bedah Onkologi Diagnosis dan Terapi Edisi Ke 2. Sagung Seto. 2002

12. Cao F, Xie B, Cui B, Xu D. Endoscopic vs. conventional thyroidectomy for the treatment of benign thyroid tumors: A retrospective study of a 4-year 


\section{Tinjauan Pustaka}

experience. Exp Ther Med. 2011;2(4):661-6.

13. Qu R, Li J, Yang J, Sun P, Gong J, Wang C. Treatment of differentiated thyroid cancer: can endoscopic thyroidectomy via a chest-breast approach achieve similar therapeutic effects as open surgery? Surgical Endoscopy 2018; doi: 10.1007/s00464-018-6221-1.

14. Ikeda Y, Takami H, Tajima G, Sasaki Y, Takayama J, Kurihara H, et al. Section 2. Thyroid total endoscopic thyroidectomy: axillary or anterior chest approach. Biomed Pharmacother. 2002;56:72s-8s

15. Kang JB, Kim EY, Park YL, Park $\mathrm{CH}$, Yun JS. A comparison of postoperative pain after conventional open thyroidectomy and singleincision, gasless, endoscopic transaxillary thyroidectomy: a single institute prospective study. Ann Surg Treat Res. 2017 Jan; 92(1): 9-14.

16. Kim EY, Lee KH, Park YL, Park $\mathrm{CH}$, Lee CR, Jeong JJ, et al. Singleincision, gasless, endoscopic transaxillary total thyroidectomy: A feasible and oncologic safe surgery in patients with papillary thyroid carcinoma. J Laparoendosc Adv Surg Tech. 2017;27(11):1158-64.

17. Kim K, Lee S, Bae JS, Kim JS. Comparison of long-term surgical outcome between transaxillary endoscopic and conventional open thyroidectomy in patients with differentiated thyroid carcinoma: a propensity score matching study. Surg Endosc [Internet]. 2020;(0123456789). Available from: https://doi.org/10.1007/s00464-02007721-2

18. Park KN, Jung CH, Mok JO, Kwak JJ, Lee SW. Prospective comparative study of endoscopic via unilateral axillobreast approach versus open conventional total thyroidectomy in patients with papillary thyroid carcinoma. Surg
2016;30(9):3797-801.

19. Cho MJ, Park KS, Cho MJ, Yoo YB, Yang JH. A comparative analysis of endoscopic thyroidectomy versus conventional thyroidectomy in clinically lymph node negative thyroid cancer. Ann Surg Treat Res. 2015;88(2):69-76.

20. Tan Z, Gu J, Han Q, Wang W, Wang $\mathrm{K}$, Ge $\mathrm{M}$, et al. Comparison of Conventional Open Thyroidectomy and Endoscopic Thyroidectomy via Breast Approach for Papillary Thyroid Carcinoma. International Journal of Endocrinology 2015; doi: 10.1155/2015/239610

21. Ahn J Hyuk, Yi JW. Transoral endoscopic thyroidectomy for thyroid carcinoma: outcomes and surgical completeness in 150 singlesurgeon cases. Surg Endosc [Internet]. 2020;34(2):861-7.

22. Lin P, Liang F, Cai Q, Han P, Chen R, Xiao Z, et al. Comparative study of gasless endoscopic selective lateral neck dissection via the anterior chest approach versus conventional open surgery for papillary thyroid carcinoma. Surgical Endoscopy 2020; doi:10.1007/s00464-020-07434-6

23. Yang Y, Sun D, Yang J, Chen J, Duan Y. Endoscopic Thyroidectomy in Anterior Chest Approach Versus Open Thyroidectomy for Patients with Papillary Thyroid Carcinomas, a Retrospective Study. Journal of Laparoendoscopic \& Advanced Surgical Techniques 2020;30(5):1-7. doi:10.1089/lap.2019.0694

24. Qu R, Li J, Jingge Y, Sun P, Gong J, Wang C. Treatment of differentiated thyroid cancer: can endoscopic thyroidectomy via a chest-breast approach achieve similar therapeutic effects as open surgery? Surgical Endoscopy 2018; doi:10.1007/s00464-018-6221-1 


\section{Tinjauan Pustaka}

25. Kim SK, Kang SY, Youn HJ, Jung

SH. Comparison of conventional thyroidectomy and endoscopic thyroidectomy via axillo-bilateral breast approach in papillary thyroid carcinoma patients. Surgical Endoscopy 2015; doi:10.1007/s00464-015-4624-9

26. Alramadhan M, Choe JH, Lee JH, Kim JH, Kim JS. Propensity scorematched analysis of the endoscopic bilateral axillo-breast approach (BABA) versus conventional open thyroidectomy in patients with benign or intermediate fine-needle aspiration cytology results, a retrospective study. International Journal of Surgery 2017;48:9-15.

27. YS Chung, JH Choe, KH Kang, SW Kim, KW Chong, KS Park, et al. Endoscopic thyroidectomy for thyroid malignancies: comparison with conventional open thyroidectomy. World J Surg 2007;31(12):2302-2306.

28. JY Choi, KE Lee, KW Chung, SW Kim, JH Choe, Koo do H, et al. Endoscopy thyroidectomy via bilateral axillo-breast approach (BABA): review of 512 cases in a single institute. Surg Endosc 2012;26(4):948-955.

29. HJ Song, KM Nam, JD Kim, CY Park, YS Kim. Looking for optimized weights of CA125 and HE4 in early screening system of ovarian cancer for Korean patients. Technol Health Care 2015;24:S163S170.

30. Pan JH, Zhou H, Zhao XX, Ding H, Wei L, Qin L et al. Robotic thyroidectomy versus conventional open thyroidectomy for thyroid cancer: a systematic review and meta-analysis. Surg Endosc 2017;31(10):3985-4001.
31. Owaki T, Nakano S, Arimura K, Aikou T. The ultrasonic coagulating and cutting system injures nerve function. Endoscopy, 2002;34(7):575-579.

32. Rao AD, Singaporewalla RM, Majumder A. Minimally Invasive Video-assisted Thyroidectomy vs Conventional Open Hemithyroidectomy in Asian Patients. World J Endoc Surg 2016;8(3):189-192.

33. Gagner M. Endoscopic subtotal parathyroidectomy in patients with primary hyperparathyroidism. The British Journal of Surgery 1996;83(6):875.

34. Miccoli P, Berti P, Raffaelli M, Conte M, Materazzi G, Galleri D. Minimally invasive video-assisted thyroidectomy. American Journal of Surgery 2001;181(6):567-570.

35. Kitano H, Fujimura M, Kinoshita T, Kataoka H, Hirano M, Kitajima K. Endoscopic thyroid resection using cutaneous elevation in lieu of insufflation. Surg Endosc 2002;16:88-91. 


\section{Daftar Tabel}

Tabel 1. Perbandingan tiroidektomi endoskopik dan tiroidektomi terbuka berdasarkan studi Kim $\operatorname{dkk}(2017)^{16}$

\begin{tabular}{llllll}
\hline $\begin{array}{l}\text { Teknik } \\
\text { pembedahan }\end{array}$ & Hipokalsemia & Hipokalsemia & $\begin{array}{l}\text { Cedera } \\
\text { nervus } \\
\text { laringeus } \\
\text { sementara }\end{array}$ & $\begin{array}{l}\text { Cedera } \\
\text { nervus } \\
\text { laringeus } \\
\text { permanen }\end{array}$ & $\begin{array}{l}\text { Nyeri } \\
\text { pascabedah }\end{array}$ \\
\hline $\begin{array}{l}\text { Tiroidektomi } \\
\text { endoskopik }\end{array}$ & $45(22,4 \%)$ & $3(2,7 \%)$ & $17(15 \%)$ & $1(0,5 \%)$ & $3,22 \pm 0,82$ \\
$\begin{array}{l}\text { Tiroidektomi } \\
\text { terbuka }\end{array}$ & $151(28,1 \%)$ & $14(2,6 \%)$ & $25(4,6 \%)$ & $4(0,7 \%)$ & $4,51 \pm 1,1$ \\
Nilai p & $<0,001$ & 1,0 & $<0,001$ & 0,28 & 0,697 \\
\hline
\end{tabular}

Tabel 2. Perbandingan tiroidektomi endoskopik dan tiroidektomi terbuka berdasarkan studi Kim $\operatorname{dkk}(2020)^{17}$

\begin{tabular}{lll}
\hline $\begin{array}{l}\text { Teknik } \\
\text { pembedahan }\end{array}$ & $\begin{array}{l}\text { Cedera } \\
\text { nervus } \\
\text { laringeus }\end{array}$ & Hipokalsemia \\
\hline $\begin{array}{l}\text { Tiroidektomi } \\
\text { endoskopik }\end{array}$ & $8,4 \%$ & $1 \%$ \\
$\begin{array}{l}\text { Tiroidektomi } \\
\text { terbuka }\end{array}$ & $7,5 \%$ & $0,6 \%$ \\
Nilai p & 0,576 & 0,2 \\
\hline
\end{tabular}

Tabel 3. Perbandingan tiroidektomi endoskopik dan tiroidektomi terbuka berdasarkan studi Park dkk $(2015)^{18}$

\begin{tabular}{lllll}
\hline $\begin{array}{l}\text { Teknik } \\
\text { pembedahan }\end{array}$ & $\begin{array}{l}\text { Cedera } \\
\text { nervus } \\
\text { laringeus }\end{array}$ & $\begin{array}{l}\text { Cedera } \\
\text { nervus } \\
\text { laringeus }\end{array}$ & Hipokalsemia & sementara \\
& sementara & permanen & & Permanen \\
\hline $\begin{array}{l}\text { Tiroidektomi } \\
\text { endoskopik }\end{array}$ & $4 / 50(8 \%)$ & $2 / 50(4 \%)$ & $13 / 50(26 \%)$ & $2 / 50(4 \%)$ \\
$\begin{array}{l}\text { Tiroidektomi } \\
\text { terbuka }\end{array}$ & $7 / 102(6,9 \%)$ & $4 / 102$ & $23 / 102(22,5 \%)$ & $3 / 102(2,9 \%)$ \\
Nilai p & 0,440 & 0,482 & 0,687 & 0,664 \\
\hline
\end{tabular}




\section{Daftar Tabel}

Tabel 4. Perbandingan tiroidektomi endoskopik dan tiroidektomi terbuka berdasarkan studi Cho dkk $(2015)^{19}$

\begin{tabular}{lllll}
\hline $\begin{array}{l}\text { Teknik } \\
\text { pembedahan }\end{array}$ & $\begin{array}{l}\text { Hipokalsemia } \\
\text { sementara }\end{array}$ & $\begin{array}{l}\text { Hipokalsemia } \\
\text { permanen }\end{array}$ & $\begin{array}{l}\text { Cedera } \\
\text { nervus } \\
\text { laringeus } \\
\text { sementara }\end{array}$ & $\begin{array}{l}\text { Cedera } \\
\text { nervus } \\
\text { laringeus } \\
\text { permanen }\end{array}$ \\
\hline $\begin{array}{l}\text { Tiroidektomi } \\
\text { endoskopik }\end{array}$ & 23 & 0 & 1 & 1 \\
$\begin{array}{l}\text { Tiroidektomi } \\
\text { terbuka }\end{array}$ & 22 & 1 & 1 & 0 \\
& & 0,297 & 0,952 & 0,341 \\
\hline Nilai p & 0,850 & 0,0 & \\
\hline
\end{tabular}

Tabel 5. Perbandingan tiroidektomi endoskopik dan tiroidektomi terbuka berdasarkan studi Tan dkk $(2015)^{20}$

\begin{tabular}{lll}
\hline $\begin{array}{l}\text { Teknik } \\
\text { pembedahan }\end{array}$ & $\begin{array}{l}\text { Cedera } \\
\text { nervus } \\
\text { laringeus } \\
\text { sementara }\end{array}$ & $\begin{array}{l}\text { Hipokalsemia } \\
\text { sementara }\end{array}$ \\
\hline $\begin{array}{l}\text { Tiroidektomi } \\
\text { endoskopik }\end{array}$ & $1(2,9 \%)$ & 0 \\
$\begin{array}{l}\text { Tiroidektomi } \\
\text { terbuka }\end{array}$ & 0 & $1(3,3 \%)$ \\
Nilai p & 0,321 & 0,43 \\
\hline
\end{tabular}




\section{Daftar Tabel}

Tabel 6. Perbandingan tiroidektomi endoskopik dan tiroidektomi terbuka berdasarkan studi Ahn dkk $(2019)^{21}$

\begin{tabular}{lllll}
\hline $\begin{array}{l}\text { Teknik } \\
\text { pembedahan }\end{array}$ & $\begin{array}{l}\text { Cedera } \\
\text { nervus } \\
\text { laringeus } \\
\text { sementara }\end{array}$ & $\begin{array}{l}\text { Cedera } \\
\text { nervus } \\
\text { laringeus } \\
\text { permanen }\end{array}$ & $\begin{array}{l}\text { Hipokalsemia } \\
\text { sementara }\end{array}$ & Hipokalsemia \\
permanen
\end{tabular}

Tabel 7. Perbandingan tiroidektomi endoskopik dan tiroidektomi terbuka berdasarkan studi Lin dkk $(2020)^{22}$

\begin{tabular}{lllllll}
\hline $\begin{array}{l}\text { Teknik } \\
\text { pembedahan }\end{array}$ & $\begin{array}{l}\text { Cedera } \\
\text { nervus } \\
\text { laringeus } \\
\text { sementara }\end{array}$ & $\begin{array}{l}\text { Cedera } \\
\text { nervus } \\
\text { laringeus }\end{array}$ & $\begin{array}{l}\text { Hipokalsemi } \\
\text { a sementara }\end{array}$ & $\begin{array}{l}\text { Cedera } \\
\text { RLN }\end{array}$ & $\begin{array}{l}\text { Cedera } \\
\text { pervus } \\
\text { laringeus }\end{array}$ & $\begin{array}{l}\text { Nyeri } \\
\text { pascabedah }\end{array}$ \\
& & & permanen & \\
\hline $\begin{array}{l}\text { Tiroidektomi } \\
\text { endoskopik }\end{array}$ & 0 & 0 & 1 & 0 & 0 & $3,1 \pm 1,2$ \\
$\begin{array}{l}\text { Tiroidektomi } \\
\text { terbuka }\end{array}$ & 0 & 0 & 1 & 0 & 0 & $3,2 \pm 2,4$ \\
Nilai p & - & - & 1,000 & - & - & 0,093 \\
\hline
\end{tabular}




\section{Daftar Tabel}

Tabel 8. Perbandingan tiroidektomi endoskopik dan tiroidektomi terbuka berdasarkan studi Yang dkk $(2020)^{23}$

\begin{tabular}{lllll}
\hline $\begin{array}{l}\text { Teknik } \\
\text { pembedahan }\end{array}$ & $\begin{array}{l}\text { Hipokalsemia } \\
\text { sementara }\end{array}$ & $\begin{array}{l}\text { Hipokalsemia } \\
\text { permanen }\end{array}$ & $\begin{array}{l}\text { Cedera nervus } \\
\text { laringeus } \\
\text { sementara }\end{array}$ & $\begin{array}{l}\text { Cedera nervus } \\
\text { laringeus } \\
\text { permanen }\end{array}$ \\
\hline $\begin{array}{l}\text { Tiroidektomi } \\
\text { endoskopik }\end{array}$ & 0 & 0 & $6,125 \pm 1,951$ & 0 \\
$\begin{array}{l}\text { Tiroidektomi } \\
\text { terbuka }\end{array}$ & 0 & 0 & $5,693 \pm 2,022$ & 0 \\
& & - & 0,133 & - \\
Nilai p & - & - & & \\
\hline
\end{tabular}

Tabel 9. Perbandingan tiroidektomi endoskopik dan tiroidektomi terbuka berdasarkan studi Qu dkk $(2018)^{24}$

\begin{tabular}{lllll}
\hline $\begin{array}{l}\text { Teknik } \\
\text { pembedahan }\end{array}$ & $\begin{array}{l}\text { Hipokalsemia } \\
\text { sementara }\end{array}$ & $\begin{array}{l}\text { Hipokalsemia } \\
\text { permanen }\end{array}$ & $\begin{array}{l}\text { Cedera nervus } \\
\text { laringeus sementara }\end{array}$ & $\begin{array}{l}\text { Cedera nervus } \\
\text { laringeus } \\
\text { permanen }\end{array}$ \\
\hline $\begin{array}{l}\text { Tiroidektomi } \\
\text { endoskopik }\end{array}$ & $4(10 \%)$ & 0 & 0 & 0 \\
$\begin{array}{l}\text { Tiroidektomi } \\
\text { terbuka }\end{array}$ & $2(5,6 \%)$ & 0 & $1(2,8 \%)$ & 0 \\
Nilai p & 0,771 & - & 0,474 & - \\
\hline
\end{tabular}




\section{Daftar Tabel}

Tabel 10. Perbandingan tiroidektomi endoskopik dan tiroidektomi terbuka berdasarkan studi Kim dkk $(2015)^{25}$

\begin{tabular}{lllll}
\hline $\begin{array}{l}\text { Teknik } \\
\text { pembedahan }\end{array}$ & $\begin{array}{l}\text { Hipokalsemia } \\
\text { sementara }\end{array}$ & $\begin{array}{l}\text { Hipokalsemia } \\
\text { permanen }\end{array}$ & $\begin{array}{l}\text { Cedera nervus } \\
\text { laringeus } \\
\text { sementara }\end{array}$ & $\begin{array}{l}\text { Cedera nervus } \\
\text { laringeus } \\
\text { permanen }\end{array}$ \\
\hline $\begin{array}{l}\text { Tiroidektomi } \\
\text { endoskopik }\end{array}$ & $22(12,7 \%)$ & $3(1,7 \%)$ & $12(6,9 \%)$ & $1(0,6 \%)$ \\
$\begin{array}{l}\text { Tiroidektomi } \\
\text { terbuka }\end{array}$ & $246(29,6 \%)$ & $15(1,7 \%)$ & $33(4,0 \%)$ & $3(0,4 \%)$ \\
Nilai p & $<0,0001$ & 1,000 & 0,104 & 0,532 \\
\hline
\end{tabular}




\section{Daftar Tabel}

Tabel 11. Rangkuman cedera nervus laringeus, hipokalsemia, dan nyeri pascabedah dari tiroidektomi endoskopik

\begin{tabular}{|c|c|c|c|c|c|c|}
\hline $\begin{array}{l}\text { Penulis, } \\
\text { tahun }\end{array}$ & $\mathbf{N}$ & $\begin{array}{l}\text { Hipokalsemia } \\
\text { sementara }\end{array}$ & $\begin{array}{l}\text { Hipokalsemia } \\
\text { permanen }\end{array}$ & $\begin{array}{l}\text { Cedera } \\
\text { RLN } \\
\text { sementara }\end{array}$ & $\begin{array}{l}\text { Cedera } \\
\text { RLN } \\
\text { permanen }\end{array}$ & $\begin{array}{l}\text { Nyeri } \\
\text { pascabedah }\end{array}$ \\
\hline $\begin{array}{l}\text { Kim dkk, } \\
2017\end{array}$ & 200 & $45(22,4 \%)$ & $3(2,7 \%)$ & $17(15 \%)$ & $1(0,5 \%)$ & $3,22 \pm 0,82$ \\
\hline $\begin{array}{l}\text { Kim dkk, } \\
2020\end{array}$ & 668 & $1 \%$ & - & $8,4 \%$ & - & - \\
\hline $\begin{array}{l}\text { Park dkk, } \\
2015\end{array}$ & 50 & $13 / 50(26 \%)$ & $2 / 50(4 \%)$ & $4 / 50(8 \%)$ & $2 / 50(4 \%)$ & - \\
\hline $\begin{array}{l}\text { Cho dkk, } \\
2015\end{array}$ & 49 & 23 & 0 & 1 & 1 & - \\
\hline Tan dkk, 2015 & 34 & 0 & - & $1(2,9 \%)$ & - & - \\
\hline $\begin{array}{l}\text { Ahn dkk, } \\
2019\end{array}$ & 150 & 5 & 2 & 7 & 1 & - \\
\hline Lin dkk, 2020 & 31 & 1 & 0 & 0 & 0 & $3,1 \pm 1,2$ \\
\hline $\begin{array}{l}\text { Yang dkk, } \\
2020\end{array}$ & 85 & 0 & 0 & $\begin{array}{l}6,125 \pm \\
1,951\end{array}$ & 0 & \\
\hline Qu dkk, 2018 & 40 & $4(10 \%)$ & 0 & 0 & 0 & - \\
\hline $\begin{array}{l}\text { Kim dkk, } \\
2015\end{array}$ & 173 & $22(12,7 \%)$ & $3(1,7 \%)$ & $12(6,9 \%)$ & $1(0,6 \%)$ & - \\
\hline
\end{tabular}

